\title{
PENANAMAN TOLERANSI BERAGAMA PADA ANAK MELALUI PENDIDIKAN
}

\author{
Nurhattati Fuad \\ Dosen Pascasarjana Universitas Negeri Jakarta
}

\begin{abstract}
As a plural nation, peaceful culture is necessary to be developed and to be built in order to foster local, national, regional, and global security. For this purpose, programs on religious tolerance are important, urgent, strategic, and determinative. In particular building peace culture is needed to accelerate national developmental programs. Consequently, from socio-political perspective the developmental programs are systemicly determined by how far religious tolerance or peace culture is successfully carried out. This article endevors to analytically describe the urgency of religious tolerance in strengtening the peace culture in Indonesia. In her analysis the religious tolerance plays very important roles that might be regarded as precondition for successful development and empowerment of NKRI (Unified state of Republic of Indonesia). For gaining its effectivity, cultivating religious tolerance culture is pivotal to be intensively implemented in our country.
\end{abstract}

KEYWORDS: religious tolerance, peace culture, security, development, informal (family) education

ABSTRAK: Sebagai bangsa majemuk, budaya damai merupakan hal niscaya yang harus dibangun dan 
dikembangkan untuk menciptakan keamanan lokal, nasional, regional, maupun global. Dalam rangka itu, program toleransi beragama menduduki peran penting, strategis, dan determinatif. Keberhasilan pengembangan budaya damai dan keamanan-yang menjadi prakondisi program pembangunan nasional-secara sosio-politik, ditentukan oleh sejauh mana tingkat keberhasilan program penguatan toleransi beragama dalam masyarakat. Artikel ini, mencoba menggambarkan bagaimana urgensi toleransi beragama dalam konstelasi penguatan budaya damai, keamanan nasional, dalam rangka penguatan Negara Kesatuan Republik Indonesia (NKRI) yang bermartabat. Dalam analisisnya, digarisbawahi bahwa toleransi beragama bagi masyarakat Indonesia merupakan prasyarat kemapanan NKRI dan efektivitas pembangunan yang tengah berlangsung. Untuk itu, penanaman nilai-nilai toleransi beragama, sebagai implikasinya, menjadi penting untuk diintensifikasikan melalui pendidikan keluarga.

KATA KUNCI: toleransi beragama, budaya damai, keamanan, pembangunan, pendidikan keluarga

\section{PENGANTAR}

Salah satu kebutuhan terpenting masyarakat dunia adalah kebutuhan dasar berupa keamanan global (global security). Kebutuhan dasar ini, tentu saja, hanya bisa diwujudkan jikalau terdapat kehidupan damai (peaceful life) di antara masyarakat antarbangsa. Kehidupan yang aman dan damai, secara 
sistemik, menjadi sebuah keniscayaan yang tak terelakkan kehadirannya. Teori-teori ilmu sosial, membuktikan bahwa keamanan global sangat ditentukan oleh faktor sejauh mana tingkat kondusivitas dan resiprokalitas komunikasi yang terbangun di antara masyarakat dunia. Aman dan damai-apa pun bentuk, motif, dan latarnya-menjadi faktor penentu tingkat keberhasilan aktualisasi suatu bangsa, masyarakat, atau individu. Aman dan damai memberi peluang efektif keberhasilan proses perubahan konstruktif dan progresif. Upaya pembangunan, sebagai proses dinamik perubahan, dengan demikian, sangat ditentukan kehadiran kedamaian dan keamanan lingkungannya. Damai dan aman adalah prakondisi yang determinatif bagi program pembangunan.

Optimalitas hasil pembangunan, sangat dipengaruhi faktor kondisi ini. Tanpa kehadiran konkretnya, karena itu, bukan hanya secara sosio-psikologis berdampak pada ketidakmampuan warga memenuhi kebutuhan dasarnya untuk beraktualisasi diri secara optimal, namun pada spektrum luas, berpotensi menjadi "faktor kendala" yang mengganggu kelancaran, efisiensi, dan efektivitas laju pembangunan. Dengan kata lain, dapat digarisbawahi pula bahwa, keberhasilan program-program pembangunan suatu bangsa juga sangat ditentukan oleh faktor "sejauh mana" kualitas keamanan dan kedamaian terbangun sebagai modal sosiopolitis (socio-political capitals) yang niscaya.

Begitu penting, strategis, dan urgensinya bagi manusia, maka adalah sangat tepat dan prospektif jikalau nilai keamanan (social security values) dan nilai kedamaian (peace-values) 
ditahbiskan sebagai "modal dasar pembangunan", seperti diamanatkan dalam Universal Declaration of Human Rights":

There can be no sustainable development without peace and security. Peace and security, development and human rights are the pillars of the United Nation system and the foundations for collective security and well-being. Development, peace and security and human rights are interlinked and mutually reinforcing. ${ }^{2}$

Tuntutan sosial, politik, ekonomi, kultural, dan keagamaan adalah jelas bahwa apa pun program penguatan atau peningkatan kualitas tata kehidupan damai dan aman menjadi penting dan niscaya penerapan konkretnya. Salah satu upaya ke arah penciptaan kondisi "damai" (being peaceful) dan "aman" (being secure) dapat dibangun melalui penguatan "toleransi beragama". Apalagi bagi masyarakat Indonesia yang notabene berlatar sangat majemuk yang tengah membangun.

${ }_{1}$ Ada tiga pasal pokok dalam The Universal Declaration of Human Rights, yang menggaris-bawahi keharusan kondisi keamanan atau kedamaian harus dipenuhi setiap manusia. Pasal 3 "Everyone has the right to life, liberty and security of person"; pasal 20 "Everyone has the right to freedom of peaceful assembly and association", dan pasal 22 "Everyone, as a member of society, has right to social security and entitled to realization". United Nations, "The Universal Declaration of Human Rights", The United Nations, diunduh 16 Oktober 2014, http://un.org.com.

${ }^{2}$ United Nation, Resolution adopted by General Assembly: 60/1-2005 World Summit Outcome, (September 2005), I.9. 


\section{POTRET BURAM INDONESIA}

Indonesia adalah negara kepulauan terbesar dengan pemilikan pulau terbanyak di dunia, terbentang dari Sabang sampai Papua. ${ }^{3}$ Sebagai negara bermasyarakat majemuk, pada 2014, Indonesia berpenduduk 250 juta, dengan tingkat kemajemukan suku, agama, bahasa, tradisi, dan budaya yang luar biasa. Secara etnologi, terdapat 1.340 suku dari 300 kelompok etnik (suku bangsa), dan 726 bahasa daerah-di mana sekitar 300 bahasa daerah yang (masih) aktif dipakai (local living languages), ${ }^{4}$ serta 6 (enam) agama besar yang termaktub dalam konstitusi, yaitu Islam, Kristen, Katolik, Hindu, Buddha, dan Konghucu, serta lebih dari 50-an kepercayaan lokal (local faiths, local beliefs). ${ }^{5}$

Kemajemukan (pluralitas) masyarakat Indonesia sebagai anugerah Sang Pencipta, sesungguhnya, merupakan kekayaan

3 Tercatat, Republik Indonesia merupakan negara maritim terbesar dengan jumlah pulau lebih dari 17.508. Lihat National Team on the Standardization of Geographical Names, National Authority on Geographical Names, (Jakarta: National Team on the Standardization of Geographical Names, 2006).

${ }^{4}$ Badan Sesus Penduduk, Sensus Penduduk 2010, (Jakarta: BPS Pusat, 2011), dan M. Paul Lewis (ed.), "Languages of Indonesia" An Ethnologue Country Report, (Dallas: SIL International, 2013), 324.

${ }^{5}$ Di Indonesia, pada 2011, terdapat lebih dari 78 paham, aliran atau gerakan keagamaan-baik sebagai keyakinan lokal murni pribumi asli (indigenous local faiths), campuran antara keyakinan lokal dengan agama pendatang (syncretic local religions/faiths), maupun aliran sempalan (religious sects) dari agama besar. Wakhid Sugiyarto dan Syaiful Arif, Direktori Paham, Aliran dan Gerakan Keagamaan di Indonesia (Jakarta: Puslitbang Kehidupan Beragama, Badan Litbang dan Diklat Kemenag RI., 2012), 56. 
bangsa, dan modal pembangunan (socio-cultural capitals for development) untuk mencapai tujuan bangsa: kehidupan yang adil, makmur, aman, dan sejahtera. Sebaliknya, jikalau tidak dikondisikan secara baik, tepat, dan proporsional, kemajemukan yang dimiliki bangsa, justru menjadi beban dan kendala pembangunan. Kemajemukan, secara sosiologis, dapat menjadi faktor integratif (faktor pemersatu) tapi sekaligus juga bisa menjadi faktor disintegratif (pemecah) bangsa. Berdasarkan keyakinan faktual ini, pengelolaan "kemajemukan, keragaman, kekayaan perbedaan" kualitas bangsa yang tepat berdasarkan prinsip-prinsip kemanusiaan, keadilan, nondiskriminasi secara politik, hukum, ekonomi, budaya, pendidikan-akan menjadi potensi yang kuat dan prospektif bagi pencapaian keberhasilan pembangunan atau percepatan kemajuan. Tanpa pewujudan sikap, komitmen, dan perlakuan yang tepat, justru sebaliknya akan melahirkan suasana kontraproduktif bagi pembangunan, karena akan melahirkan suasana "chaotic", kurang stabil, "partially-disfunctional" yang mengundang terjadinya konflik sosial-baik konflik nyata yang tampak (manifest conflict) maupun konflik tersembunyi (hidden/latent conflict).

Pengalaman pahit terjadinya konflik sosial pada beberapa dekade lalu, misalnya, secara sosiopolitik, pada dasarnya diakibatkan kebijakan pengelolaan kemajemukan yang kurang tepat. Fenomena konfliktual yang terjadi paling tidak sejak dekade akhir abad XX dan awal abad XXI merupakan bentuk konflik "multifaceted" sebagai pengristalan berbagai situasi krisis kebijakan sebelumnya di Indonesia. Dimulai dengan 
peristiwa penjarahan pertokoan, pembunuhan, dan pemerkosaan terhadap non-pribumi pada Mei 1998, kemudian berlanjut dengan kemunculan berbagai bentuk konflik, seperti konflik bernuansa agama (pembakaran gereja di Ketapang, Jakarta 1999, pembakaran mesjid di Kupang, 1999); Konflik berbasis etnis seperti peristiwa Sambas; Konflik vertikal daerahpusat (konflik Aceh, Riau, Papua, Poso, Maluku Utara); Konflik partai, dan konflik multi-faktor (multifaceted-based conflicts). Kemudian, pada era relatif sama, angka kerusuhan sosial meningkat secara signifikan. Demo-demo protes ketidakpuasan terhadap kebijakan pemerintah dalam berbagai persoalan praktis - politik, ekonomi, budaya, pendidikan, dsb., ditambah dengan "keributan sosial" (social riots) pada skala kecil seperti tawuran antar-komunitas (seperti tawuran warga kampung, anak sekolah/mahasiswa, gengs) dalam berbagai modus operandinya pada dasarnya merupakan potret buram representasi pengalaman pahit Indonesia yang perlu perbaikan untuk penguatan NKRI yang sejahtera, aman dan damai.

\section{MANAJEMEN KONFLIK AGAMA: SEBUAH PROGRAM PRIORITAS}

Sebagai makhluk berakal (homo sapiens), manusia merepresentasikan dirinya juga sebagai makhluk beragama (homo religiosus). Sebagai makhluk beragama, manusia secara fitrati berkecenderungan membutuhkan "sesuatu" yang diyakini sebagai obyek pengabdian dan persembahan yang diposisikan sebagai dzat maha tinggi dan maha kuasa atas ciptaannya-sebagai dzat yang mengada sebagai "mysterium 
tremendum fascinosum". ${ }^{6}$ Kecenderungan alamiah inilah, maka "agama" dalam kenyataannya dipandang memiliki makna penting dan mendasar. Pada kondisi tertentu, bahkan, agama menjadi "unsur utama" dalam kehidupan manusia. Agama diyakini mampu menjalankan fungsi salvatifnya untuk meraih tujuan terakhir dari keseluruhan proses kehidupan itu sendiri (the ultimate goal). Argumen deontologik inilah yang menjawab mengapa agama dipersepsi sangat penting, diterima, dan diyakini sejak kehadiran manusia di seluruh belahan dunia. Agama dipeluk secara lintas batas ruang, ras, suku, dan kebudayaan. Walau, dalam realitas sosio-teologisnya, faktanya hingga kini belum terdapat rumusan konseptual ikhwal agama yang memuaskan semua pihak. Meskipun demikian, agama tetap ditempatkan sebagai institusi kultural yang sentral oleh masyarakat di sepanjang sejarah peradabannya. Fakta sejarah menunjukkan bahwa $84 \%$ lebih penduduk dunia mengakui keberadaan agama. Hanya $16 \%$ saja yang menolak agama sebagai bagian dari kehidupan dikarenakan faktor latar belakang tertentu. ${ }^{7}$ Joachim Wach merumuskan agama sebagai

${ }^{6}$ Istilah dari Das Heilige (1917) atau "The Idea of the Holy: An Inquiry into the Non-Rational Factors in the Idea of the Devine and Its Relation to the Rational," oleh Rudolf Otto, teolog Jerman (1869-1937), yang berarti "(Tuhan) sebagai sesuatu yang menakutkan, menggetarkan, tapi sekaligus juga mempesonakan." Lihat Craig Calhoun, et al, Sociology (New York: MacGraw-Hill, 1994).

7 United Nations, Population of the World, 25 Maret 2009, diunduh Juli 2012, http://www.un.org/en/development/desa/population. Laporan ini menyebut dari total penduduk dunia, 6.8 milyar lebih, diantaranya 29\% pemeluk agama Kristen (Katolik dan Protestan), $24 \%$ Islam, $14 \%$ 
realitas sosial yang ditandai oleh sedikitnya tiga corak pengungkapannya, yaitu sebagai sistem kepercayaan (belief system), sistem persembahan (system of worship) dan sistem hubungan sosial (system of social relation). ${ }^{8}$ Emile Durkheim, sosiolog pemrakarsa analisis sosiologis tentang agama mendefinisikan agama sebagai "unified system of beliefs and practices related to sacred things." Agama dikonsepsi sebagai sistem kepercayaan dan praktek di mana suatu masyarakat atau kelompok berjaga-jaga menghadapi persoalan terakhir. Agama, terutama agama wahyu (revealed religion) ${ }^{9}$, memiliki tiga dimensi dasar religiositas, yaitu: dimensi keyakinan, praktek, dan pengalaman beragama. ${ }^{10}$

Hinduisme, 16\% Tak Beragama (Nonreligion), sisanya adalah pemeluk Budhisme, syncretism, dll. Sementara, CIA menyebut angka yang berbeda. Pada tahun 2012 penduduk dunia berjumlah 7.021.836.029 jiwa, dengan distribusi 33,5 \% pemeluk Kristen, 22,43 \% Islam, 13,78 \% Hinduisme, 13,13 \% Buddhisme, 0,36 \% Sikh, 0,21 \% Yahudi, 0,11 \% Bahai, 11,17 \% Agama Lain, serta 9,42 \% Tidak Beragama (Non-religious), dan 2,04\% Atheis. Centra Intelligence Agency, The World Factbook (USA: CIA, July 2012).

${ }^{8}$ Lihat Joachim Wach, Sociology of Religion (Chicago: University of Chicago Press, 1944), 17-27.

${ }_{9}$ Agama wahyu (revealed religion) dan agama nir-wahyu (nonrevealed religion atau cultural religion) adalah istilah dari Ahmad A. Al-Masdoodi dalam Living Religions of the World (Karachi: Begum Aisha, 1962), 11. Menurutnya, agama wahyu adalah agama yang menuntut iman kepada Tuhan, Rasul, dan Kitabnya. Sedang agama nirwahyu adalah agama yang tidak memandang penyerahan diri dari manusia kepada aturan Ilahi sebagai sesuai yang esensial.

${ }^{10}$ Dimensi keyakinan (belief system) terkait dengan aspek keyakinan terhadap Tuhan dan ciptaannya, kemudian dimensi ritual adalah aspek yang terkait dengan tata cara peribadatan yang diajarkan oleh agama yang 
Selain ketiga dimensi keagamaan tersebut, Glock \& Stark ${ }^{11}$ menambahkan dua dimensi religiositas lain. Pertama, dimensi pengetahuan agama (religious knowledge; intellectual dimension) yang berkaitan dengan besaran atau kedalaman penguasaan ajaran agama. Kedua, dimensi efek keagamaan (religious effects) terkait bagaimana ajaran agama berpengaruh terhadap kehidupan keseharian berbagai aspek kehidupan dan sebaliknya bagaimana lingkungan berpengaruh terhadap agama itu sendiri. Selain dimensi-dimensi religiositas yang disebutkan Durkheim, Yinger, Schaefer, Glock \& Stark, dan lain-lain di atas, Ninian Smart dalam The World's Religion ${ }^{12}$ menunjukkan dua dimensi lain yaitu dimensi etis dan legal (ethical \& legal dimension) yang memuat ajaran "halal-haram"nya tindakan, dan dimensi bendawi (material dimension) menyangkut aspek bendawi sebagai hasil ekspresi fisik religiositas pemeluknya.

Dimensi-dimensi religiositas yang diurai singkat di atas, memperlihatkan betapa penting dan bermaknanya agama bagi kehidupan masyarakat. Agama menyediakan sistem keyakinan, peribadatan, dan relasi sosial. Agama, dalam realitas kehidupan keseharian, menjalankan fungsi mendasar yang

dipeluknya, sedangkan pengalaman beragama berhubungan dengan tingkat kedekatan, keakraban dan pengalaman supranatural yang dirasakan seorang pemeluk agama.

${ }_{11}$ Geoffrey K. Nelson, Cults: New Religion and Religious Creativity (London: Routledge \& Kegan Paul, 1987), 141.

${ }^{12}$ Lihat Ninian Smart, The World's Religion: Old Tradition and Modern Transformation (Cambridge: Cambridge University Press, 1989), 12-20. 
bermanfaat bagi pembentukan "moral community". Yusuf, ${ }^{13}$ menyebut agama sebagai "way of life", petunjuk, atau kerangka acuan, menjalankan sejumlah fungsi, yaitu fungsi edukatif, penyelamatan, kontrol sosial, profetik, integratif dalam rangka membangun tatanan sosial komunitas bermoral (moral community). ${ }^{14}$

Demikian banyak fungsi yang diperankan agama dalam realitas kehidupan, menjadikan agama menjadi sebuah kebutuhan dasar bagi individu atau masyarakat sebagai makhluk beragama. Peran yang diemban agama, di satu sisi, berfungsi positif dan konstruktif dalam pembentukan "komunitas bermoral" atau "komunitas beragama" yang kuat, kompak, dan solid. Namun, pada sisi lain, pada tingkat intensitas tertentu, di mana "in group feelings" tumbuh sangat kuat dan berlebihan, maka agama justru potensial mengkristalisasi terbentuknya fanatisme agama (religious fanaticism) baik dalam aspek keyakinan, ritual, pengetahuan, tradisi, dan maupun "truth claim" yang dilakukan kelompok agama. Dua kondisi asimetrik fanatisme ini, pada satu sisi, bisa menjadi faktor integratif tapi pada sisi lain bisa juga menjadi faktor disintegratif. Sebagai faktor integratif karena fanatisme

${ }^{13}$ Lihat Choirul Fuad Yusuf, Peran Agama dalam Masayarakat: Studi Awal Proses Sekularisasi pada Masyarakat Muslim Kelas Menengah (Jakarta: Badan Litbang dan Diklat Keagamaan, 2001), 25-30.

14 Komunitas bermoral (moral community) adalah masyarakat yang memiliki keyakinan kepada sesuatu yang sakral, memiliki simbol-simbol, menjalankan praktek (ritual) agamanya, dan memiliki pengalaman yang mengikat mereka bersama menjadi suatu kelompok. Calhoun, Sociology, 351. 
mampu membangun kesatuan kelompok pengikut suatu agama (jamaah) sangat solid, familiar, kompak dan "in group feeling empowering". Sebagai faktor disintegratif, karena fanatisme potensial mengonstruksi tumbuhnya sikap membedakan (feeling of difference) dari kelompok/pengikut agama yang lain yang berujung memicu tumbuhnya sikap antipati, xenophobia, dan arogansi doktriner berlebihan. Kedua karakter situasi diametrik ini, sangat potensial mengemuka menjadi sebuah konflik yang sangat destruktif bagi kehidupan. ${ }^{15}$ Itulah mengapa, di berbagai bangsa (atau negara) yang berlatar belakang multi-agama atau multi-sekte, seperti India, Filipina, Pakistan, Mesir, Irak, Irlandia, Bosnia, dsb. dihadapkan pada situasi konfliktual berbasis agama yang tak berujung. Konflik agama, bisa melahirkan "religiously-motivated abuse, violence, murder, mass-murder, terrorism and genocide"16 Ajaran ritual pengorbanan (rituals of sacrifice), keyakinan kesyahidan (martyrdom), fanatisme kebenaran mutlak, dan egokelompok emosional yang diindoktrinasikan oleh hampir seluruh agama besar merupakan argumen sosio-teologis mengapa konflik antar/inter agama memiliki derajat kompleksitas, keberlangsungan, intensitas kekerasan dan tingkat brutalitas lebih tinggi (baca: dahsyat) di antara modus konflik lainnya. Jika dibanding dengan modus konflik sosial

15 Ditengarai bahwa konflik berbasis agama cenderung lebih dahsyat, kuat, lama, dan keras dibanding dengan konflik bersumber faktor lain.

16 "Religious Peace and Confict," Ontario Consultants on Religious Tolerance, diunduh 16 Oktober 2014, http://www.religioustolerance.org. 
berlatar motif lain, seperti konflik bermotif politik praktis, ekonomi, kepartaian, sosial, dll., ternyata bentuk konflik berbasis agama cenderung terjadi berlangsung lama, kerapkali bersumber kumulatif, dan bermodus kekerasan yang lebih hebat, brutal, sadistik. Fakta sejarah mencatat bahwa:

Religious violence has probably existed for as long as religion. History has done nothing to calm the passions, hatred, and brutality expressed in the name of religion. If anything, the progress of science and technology have enabled religious extremists to hate and kill evermore effectively. Almost everyone would like to end the violence, but few understand its causes. Even worse, some religious believers are in denial about the causes and connections between violence and their religion". ${ }^{17}$

"Violence in the name of religion, plentiful enough in our time, is an enduring feature of religious life. Rituals of sacrifice and martyrdom and legendary tales of great battles abound within every religious traditions. In most cases, the violent images are symbolic, but the reality of religion is clouded with actual events of violence-inquisitions and internal attacks, sacrifices and martyrdom, wars, and conquests. Virtually every religious tradition has left a trail of blood. ${ }^{18}$

17 "Causes and Sources of Religious Violence: Why Are Religions Violent?" About Religion \& Spirituality, diunduh 18 Oktober 2014, http://www.atheism.about.com.

18 Mark Juergensmeyer dan Margo Kitts, "Introduction: Why Is Religion Violent and Violence Religious?" dalam Princeton Readings in Religion and Violence (New York: Princeton University Press, 2011), 1, diakses 
Melihat peran dan signifikansi sosial dari agama bagi masyarakat, karena itu, penataan agama menjadi urgen pula. Penerapan manajemen konflik berbasis agama secara tepat, maksimal dan optimal merupakan kebutuhan dasar yang mutlak harus dilakukan-baik diorientasikan untuk prevensi, reduksi, rehabilitasi, dan pengatasan tuntas terhadap konflik agama yang tengah terjadi. Dengan kata lain, bagi Indonesia-sebagai negara "termajemuk" suku, agama, keyakinan lokal, dan tradisi budayanya--program manajemen konflik agama menjadi kebutuhan prioritas. Paling tidak, dalam upaya: (a) penghindaran dari konflik keras berisiko tinggi, dan (b) penciptaan kondisi kondusif bagi efektivitas pembangunan, dan (c) penguatan NKRI sebagai negara bangsa yang bermartabat dalam masyarakat dunia.

\section{TOLERANSI BERAGAMA: PROBLEM KUNCI KOMUNIKASI}

Salah satu model manajemen pengatasan konflik agama di Indonesia yang mendasar adalah penguatan budaya toleransi dalam masyarakat. Fakta sejarah Indonesia, menunjukkan bahwa faktor utama sumber konflik berbasis agama ${ }^{19}$ adalah

18 Oktober 2014, http://press.princeton.edu/chapters/i9566.pdf.

19 Bahkan kerapkali terjadi dalam tipe konflik lainnya, seperti: Konflik Ambon pada awalnya disebabkan oleh "faktor pribadi" antara sopir angkutan kota dengan penumpangnya karena faktor "ongkos". Kemudian, masing-masing mengajak teman seagamanya. Perseteruan pribadi, tersebut, pada akhirnya terkristal menjadi konflik antar penganut agama berbeda (Kristen-Muslim). Ini bukti, bahwa kerapkali, agama (pengikut agama) di- 
rendahnya tingkat toleransi beragama dalam kehidupan masyarakatnya. Webster's World University Dictionary mendefinisikan "tolerance" (toleransi) sebagai : 1) liberality toward the opinion of the others dan 2) the act of permitting to go on without interference ${ }^{20}$ Sementara, kamus lain mendefiniskan toleransi sebagai : 1) "a willingness to be tolerant and patient toward people whose opinions or ways differ from one's own, 2) willing to let other people do as they think best, 3) willing to endure beliefs and actions of which one does not approve, (4) recognition of a person's rights to worship as he think best without loss of civil rights or social previleges, and (5) freedom of worship. ${ }^{21}$

Istilah atau kata toleransi (tolerance atau toleration), secara historik dipergunakan pertama kali dalam wacana kehidupan sosial sejak abad ke-15, yang menggambarkan "adanya sikap permisif dari pihak lain", yang kemudian berubah maknanya karena faktor-faktor politik, teologis, dan kultural. Pada abad Pencerahan (Enlightenment Age), tahun 1600-an, misalnya, politisi mulai menggunakan istilah toleransi dalam dua konteks kebijakan: civil tolerance dan ecclesiastical tolerance. $^{22}$ Perkembangan selanjutnya, definisi modern

politicking untuk interes lain dari kelompok, golongan, partai, dll.

${ }^{20}$ Edward N.Teall, ed., Webster's World Dictionary (Washington DC.: Publishers Company Inc., 1965), 1050.

21 E. L. Thorndike \& Clarence L. Barnhart, ed., Thorndike-Barnhart Advanced Junior Dictionary (New York: Doubleday \& Company Inc., 1965), 855.

22 John Coffey, Persecution and Toleration in Protestant England (England: Longman Publishing, 2000), 12. 
mengartikan toleransi dikaitkan dengan pandangan HAM liberal or libertarian. Dalam aspek politis, toleransi dipahami sebagai respons pragmatis dan liberal terhadap fakta keragamaan dan kebutuhan nyata akan hak-hak dasar manusia. Dalam konteks ini, muncul istilah berbagai toleransi: toleransi politik, toleransi ekonomi, toleransi budaya, toleransi sosial, dan toleransi beragama. Konsep dan manifestasi ikhwal "toleransi"-apa pun kategori, tujuan, motif, maupun prosesnya-senantiasa dirujukkan kepada hak-hak kemanusiaan yang dipandang sebagai kriteria dasar dan universal norma dan nilai yang harusnya diimplementasi dalam kehidupan keseharian. Pasal 18 UDHR, misalnya menegaskan bahwa: "Everyone has the rights to freedom of thought, conscience and religion," 23 termasuk kebebasan untuk pindah agama, keyakinan, dan hak untuk mewujudkan agamanya dalam pendidikan, ritual, peribadatan, maupun persembahan. Dalam spektrum makro, karena itu, The UN's Declaration of Principles on Tolerance, secara padat mendefinisikan "tolerance as an attitude and responsibility that upholds human rights, pluralism (including cultural pluralism), democracy and the rule of law" (toleransi merupakan sikap dan tanggung jawab yang menjunjung tinggi hak asasi manusia, pluralisme (termasuk pluralisme budaya), demokrasi dan hukum)..24

${ }^{23}$ This right includes freedom to change his religion or belief and freedom to manifest his religion or belief in teachung, practice, worship and observance. United Nations, "The Universal Declaration of Human Rights", article 18.

${ }^{24}$ UNESCO, Declaration of Principles on Tolerance, 1995. 
Berpijak pada konsep di atas, pada spektrum lebih luas, toleransi dapat dirumuskan sebagai sikap atau aktivitas yang dikonsepsikan sebagai pemberian rasa kebebasan, kontrol diri, kesabaran, solidaritas, saling menghormati, saling mengerti, saling menghargai perbedaan atau "privilege" orang lain. Toleransi beragama (religious tolerance), dengan demikian, merupakan pemberian kebebasan, solidaritas, penghargaan, penghormatan, serta pemahaman terhadap keyakinan, persembahan, peribadatan, dan perbedaan agama lain yang berbeda.

Dari perspektif psikologi, toleransi beragama dapat dipahami sebagai sikap individu yang menerima dan mengakui realitas perbedaan keyakinan, atau tindakan lainwalau menurut dirinya keyakinan tersebut salah dan seharusnya ditolak. Dengan sikap seperti ini, seorang individu dengan penuh kesadaran menerima, menghargai, dan memberi jaminan kesempatan kepada orang lain untuk secara bebas memilih sikap, dan cara hidup yang diyakininya benar. Meski sesungguhnya dirinya tidak selalu menyetujui apa yang diyakini dan disikapi orang lain, namun secara asasi dirinya sudah menjalankan kewajiban untuk memberi kebebasan mengakui realitas yang berbeda dalam kehidupan bermasyarakat. Dari perspektif epistemologik, toleransi tidak hanya menempatkan nilai kebenaran (the truth values) pada kerangka nilai kemanusiaan yang universal, namun juga pada konsep hakiki bahwa nilai kebenaran juga bisa diekspresikan melalui berbagai cara. Toleransi, dari sisi ini, memberikan ruang pada kebenaran relatif tentang realitas sosial. Toleransi 
memberi kebebasan untuk mengekspresikan kebenaran. Walau, tentu saja sebatas tidak menjegal kebebasan orang lain. Toleransi tidak memberi kebebasan untuk bertindak tanpa pembatasan.

Dari perspektif sosiologis, toleransi merupakan nilai budaya sangat penting sebagai perekat terjadinya soliditas dan solidaritas sesama anggota masyarakat. Toleransi menjadi unsur terpenting terintegrasinya subsistem-subsistem dalam masyarakat, karena mengonstruksi terbentuknya keseimbangan masyarakat (social equilibrium). Semakin toleran sebuah masyarakat, semakin terrekat dan tersatukan (integrated and unified). Sebaliknya, semakin masyarakat intoleran (bersikap tidak toleran), semakin pecah kondisi masyarakat itu sendiri, dan rentan timbulnya konflik terbuka. Lebih jauh, toleransi sebagai kondisi, sikap saling menghargai, mengerti dan mengakui perbedaan dan hak-hak dasar sesama manusia, secara sosiologis, merupakan faktor penentu terbangunnya budaya damai (peace culture). ${ }^{25}$ Toleransi beragama dalam masyarakat majemuk, menjadi salah satu unsur terpenting dan prasyarat terwujudnya keamanan lokal, nasional, regional, dan global sebagai jembatan mewujudkan negara kesatuan yang

${ }^{25}$ Budaya damai (peace culture) adalah seperangkat nilai, sikap, dan bentuk perilaku yang berfungsi menciptakan kedamaian, mengurangi konflik dan mengembangkan sikap saling pengertian terhadap perbedaan. Ekspresi budaya damai merepresentasikan keyakinan bahwa suasana damai (being peaceful) adalah kebutuhan hidup, beraktifitas, dan suasana damai adalah keadaan yang bisa dipelajari, diajarkan, dibudayakan, dan dikembangkan. 
kuat, berdaulat, dan bermartabat di tengah masyarakat dunia. Jikalau, prakondisi fungsional tersebut terpenuhi, sangat rasional bila tujuan akhir Indonesia sebagai masyarakat adil dan makmur terwujud nyata.

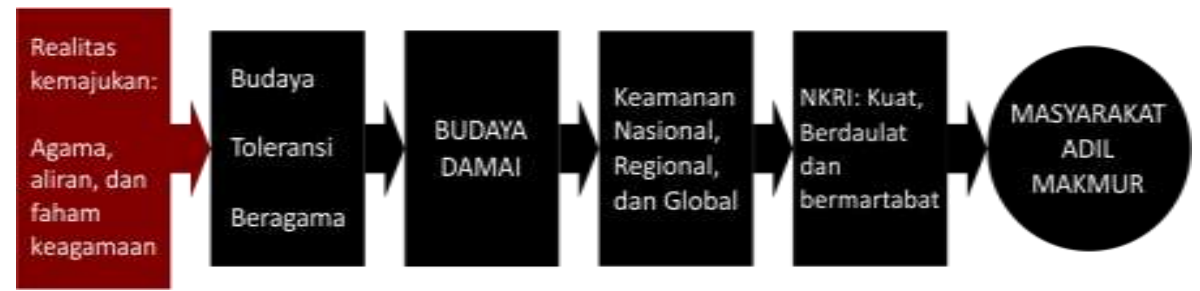

Dalam konteks prilaku beragama, sikap intoleransi beragama (religious intolerance) merupakan sikap terbalik yang secara sosio-psikologis, tidak menyukai toleransi. Keyakinan dasar (basic tenet) dari intoleransi beragama adalah bahwa perilaku beragama, doktrin, keyakinan, dan ritus (pengikut agama lain) adalah keliru, salah, tidak absah, dan tentu saja harus ditolak. Perilaku intoleran cenderung kaku (rigid), fanatik, ekstrim, eksklusif, dan menganggap rendah dalam mempersepsi, melihat, dan mengevaluasi orang lain pemeluk agama yang berbeda. Perilaku intoleran, lebih jauh, biasanya tidak mampu menerima dan menghargai opini, gagasan, tindakan, sikap dan prinsip-prinsip yang berbeda. Perilaku intoleran dalam proses komunikasi kesehariannya, ternyata tidak hanya menciptakan situasi yang tak kondusif dan dialogal dalam masyarakat, namun juga cenderung menciptakan ketengangan sosial (social tensions), tindak kekerasan, dan agresivitas dalam masyarakat. 


\section{MENGAPA INTOLERAN?}

Sebelumnya dijelaskan bahwa toleransi dikonsepsikan sebagai sikap atau tindakan individu yang didasarkan pada komitmen, kemauan, kesabaran menahan diri, rasa solidaritas dan "ke-legowo-an" untuk memberikan kebebasan dan rasa saling menghormati, menghargai, dan memahami perbedaan orang lain. Toleransi beragama (religious tolerance), pada hakikatnya, merupakan sikap atau tindakan individu yang menghargai kebebasan orang lain untuk meyakini, memeluk, dan menjalankan ibadah sesuai keyakinannya. Seorang tolerator adalah orang yang sabar, rela, bisa menahan diri, menghormati, dan menghargai orang lain yang berbeda agama, keyakinan, peribadatan, dan perilaku agamanya. Sebaliknya, intoleransi beragama (religious intolerance) adalah sikap atau tindakan menolak (takfir), tidak menghargai, dan mengkoptasi kebebasan orang lain untuk meyakini, memeluk, beribadat sesuai agamanya yang berbeda. Orang intoleran adalah orang yang tidak suka dan tidak rela atas kehadiran agama lain yang berbeda di lingkungannya. Dalam prakteknya, orang yang intoleran cenderung tidak bisa menghargai dan menghormati perbedaan keyakinan dan ritual. Orang intoleran, secara subyektif bersikap fanatik atas agama sendiri sebagai satusatunya ajaran dan kebenaran absolut, namun pada sisi obyektif dirinya meng-kafir-kan (menolak) kebenaran atau ajaran lain berbeda. Dalam prakteknya, karena itu, seorang intoleran, sulit untuk mengakui keberadaan agama lain serta sulit menghargai hak-hak kebebasan beragama yang secara dimiliki orang lain juga. Oleh karena itu, intoleransi beragama 
sangat pontensial menjadi penyebab terjadinya pergesekan atau konflik antara pengikut agama atau keyakinan yang berbeda. Intoleransi bisa menjadi "anatheme", yang menggumpal menjadi modus dedikasi bagi kejahatan dan musibah bagi kemanusiaan. Pertanyaan dasarnya adalah, "bagaimana sejatinya agama mengajarkan kepada pemeluknya dalam berinteraksi dengan penganut agama atau keyakinan yang berbeda"?

Secara teologik, sesungguhnya, semua agama-baik agama wahyu maupun agama budaya-mengajarkan kepada pemeluknya untuk bersikap dan bertindak baik dan benar sesuai dengan prinsip-prinsip kemanusiaan. Semua agama mengajarkan "kedamaian" intra dan antar agama, mengajarkan cinta kasih, menuntun ke arah kebaikan dan kebenaran. Semua agama mengamanatkan untuk saling menghargai, menghormati, dan menjunjung tinggi nilai-nilai kemanusiaan. Tiada satu pun agama mengajarkan untuk membenci, memusuhi, dan melecehkan agama atau pengikut agama lain.

Dalam kitab suci agama-agama besar, misalnya, jelas bahwa semua agama mengajarkan untuk berdamai, menciptakan suasana aman, tenteram dan sejahtera bagi umat mansia. Banyak sekali ayat-ayat dalam Kitab Suci al Qur'an, Alkitab, Weda, dsb. yang memfirmankan kepada pemeluknya untuk menciptakan suasana damai dalam kehidupan kesehariannya, seperti dalam Q.S. 17:37 dan Q.S. 4:29.26

${ }^{26}$ Dalam Q.S. 17:37, "Dan janganlah kamu berjalan di bumi ini dengan sombong, karena sesunggunya tidak akan dapat menembus bumi dan tidak akan 
Demikian pula dalam Alkitab (Mazmur 29: 11, 34:14, Korintus 14: 33, Filipi 4: 9, juga dalam Yayur Veda 36:17, dan sangat banyak firman semakna perlu membangun kedamaian, kerukunan, kasih sayang, bertoleransi dalam semua ajaran agama: Islam, Katolik, Kristen, Buddha, Hindu, Konghucu, dan agama-agama lokal. Keyakinan dasar semua agama yang mengajarkan "kedamaian", "cinta-kasih" termasuk melalui sikap toleran di antara pemeluk agama dan sesama umat manusia, secara teologis merupakan hal yang tidak rasional jikalau terjadi situasi sebaliknya, yaitu tumbuhnya sikap permusuhan dan intoleransi dalam masyarakat beragama. Kecenderungan terjadinya fenomena intoleransi dan konflik bernuansa agama, dengan demikian, pada dasarnya merupakan persoalan politis, di mana agama diseret sebagai "faktor penguat dan penarik gerbong" untuk kepentingan politik para penafsu kekuasaan. Ditambah, sejarah berdarah konflik antaragama di masa lalu, menjadikan "agama" menjadi "triggering factor" yang ampuh memicu konflik apa pun motif sebenarnya. Dalam konteks peradaban ke depan, kiranya strategi peradaban relijius yang damai menjadi kebutuhan niscaya semua pemeluk agama - sekali pun berbeda ajarannya.

mampu menjulang setinggi gunung". Q.S 4:29 "Wahai orang-orang yang beriman, janganlah kamu saling memakan harta sesamu dengan jalan yang batil (tidak benar), kecuali dalam perdagangan yang berlaku atas dasar suka sama suka diantara kamu. Dan janganlah membunuh dirimu. Sungguh Allah maha Penyayang kepadamu". Banyak lagi, ayat al Qur'an yang berbicara atau mengajarkan perlunya kedamaian, keamanan, toleransi, respek paada perbedaan, sikap saling mengerti, mencintai ciptaan atau sesama manusia. 
Agama, ke depan diidolakan sebagai "rahmatan lil 'alamin" yang memberkati semua anak bangsa.

\section{PENDEKATAN PENDIDIKAN: SEBUAH PILIHAN EFEKTIF}

Salah satu pendekatan untuk sosialisasi atau diseminasi tata nilai dan norma (norms and values system) yang tepat adalah pendekatan pendidikan (educational approach). Berbeda dari pendekatan lain, seperti pendekatan otoritanianistik, militer, atau totalitarian, maka pendekatan pendidikan cenderung memiliki nilai lebih. Pendekatan pendidikan, yang diwujudkan dalam bentuk alih-pengetahuan, tukar informasi, penyuluhan, pengajakan, pembimbingan, cenderung metodologis, cenderung lebih manusiawi dan relevan dengan era masyarakat global yang demokratis, terbuka, rasional, dan noncoercive. Sebaliknya, pendekatan yang "indoktrinatif", "memaksa", "mengondisikan secara terstruktur ketat", atau "penahbisan dogma" menjadi tak relevan lagi untuk diseminasi budaya toleransi di era kini.

Pendekatan pendidikan, bisa dilakukan memalui model pendidikan formal, nonformal, dan informal. Penerapan materinya bisa dilakukan secara terpisah dalam satu "subjectmatter" secara terpisah utuh (separated) di tempat belajar, atau secara integratif dipadukan dengan mata pelajaran lainnya, seperti dengan mata pelajaran agama, kewarganegaraan, ilmu hukum, sejarah, ilmu budaya, dan ilmu sosial atau humaniora lainnya.

Sajian pendidikan toleransi beragama, secara substantif, bisa diagendakan melalui sejumlah program "pendidikan 
toleransi", seperti melalui program: (1) penguatan kesadaran berbangsa dan bernegara, (2) penguatan pemahaman dan penerapan nilai-nilai kemanusiaan universal, (3) penguatan komitmen pemuka agama dan tokoh masyarakat untuk toleransi, (4) intensifikasi pengembangan agama inklusif, (5) penghindaran, eliminasi, atau reduksi penggunaan simbolsimbol kekerasan, (6) penguatan program pendidikan multikultural, (7) ekstensifikasi program penguatan budaya damai, (8) ekstensifikasi program penguatan penegakan hukum (law enforcement). Dan, program-program tersebut dalam implementasinya bisa diwujudkan dalam bentuk fora: dialog antar-generasi (orang tua, pemuda, anak sekolah, dsb.), kemah antar-pemeluk agama berbeda, kunjungan ke tempat ibadah agama yang berbeda, penghindaran simbol-simbol agama yang menyolok dan challenging pihak lain, pengurangan program "missionary" atau "daiyah" untuk konversi agama.

\section{PENDIDIKAN TOLERANSI DI LINGKUNGAN KELUARGA}

Salah satu pendekatan mikro untuk "structural conditioning" pembentukan sikap budaya toleransi beragama khususnya, dan pengembangan sikap multikultural masyarakat adalah melalui pendekatan pendidikan keluarga dengan sejumlah argumen. Pendidikan keluarga, secara sosiopsikologis, memegang peran penting dan determinatf dalam pendidikan toleransi dalam keluarga. Efektivitas penanaman toleransi sangat tergantung pada sejauhmana komitmen, partisipasi, pelibatan dan keaktifan sebuah keluarga sebagai 
tempat tinggal anggota keluarga, termasuk anak-anaknya. Secara sistemik, terdapat sejumlah argumen mengapa keluarga merupakan instrumen strategis dalam pembentukan sikap toleran.

Pertama, keluarga-sebagai unit terkecil dan bagian tak terpisahkan dari masyarakat merupakan institusi paling strategis bagi pembentukan kepribadian anggota keluarganya, terutama anak-anaknya. Peluang dan tingkat resiprokalitas komunikasi. Komunikasi dalam keluarga lebih intensif dibanding di luar keluarga. Demikian pula, iklim komunikasi dalam keluarga cenderung lebih mudah "dikonstruksi" ketimbang dalam institusi lebih besar. Sentuhan pribadi dan emosional anggota keluarga dalam berkomunikasi lebih intens, instrinsik, dan bermakna dibandingkan dalam bentuk suasana komunikasi transaksional di luar keluarga. Hess, Markson dan Stein (1988), menggarisbawahi posisi keluarga dalam konteks pendidikan sebagai "the primary sources of identity and meaning", untuk membentuk lingkungan yang stabil bagi pemeliharaan anak dan pembentukan emosi. ${ }^{27}$ Keluarga adalah lingkungan pertama pendidikan yang diterima anak, yang memberikan peletakan dasar kehidupan itu sendiri.

Kedua, secara psikologis, penanaman nilai atau pendidikan karakter pada usia dini potensial efektif dibanding pada masa berikutnya. Penelitian Dwi Nirmala (2012), menguatkan teori-teori sebelumnya tentang tingkat efektivitas

27 Beth B. Hess, Elizabeth W.Markson, dan Peter J.Stein, Sociology (New York: Macmillan Publishing Company, 1988), 279-280. 
pendidikan pada usia dini. Melalui penelitian itu disimpulkan bahwa penanaman karakter sejak usia dini penting dalam membentuk karakter dengan memanfaatkan masa emas (golden age) pertumbuhannya. Pada masa ini, anak dapat menyerap informasi hampir $80 \%$ yang terjadi di sekitarnya, sehingga baik untuk menanamkan karakter yang positif berupa pengetahuan, kesadaran individu, tekad, serta pemilikan kemauan untuk menerapkannya. ${ }^{28}$ Tuntutan psikologisnya, maka peran keluarga (orang tua, kakak-adik) menjadi penting dalam pemanfaatan masa emas anak. Demikian pula, pada perkembangan usia berikutnya, pada usia sekolah, peran keluarga juga tetap menjadi penting dan menentukan juga efektivitas belajar anak. Pelibatan atau partisipasi orang tua dalam membentuk lingkungan belajar yang kondusif sangat diperlukan pada perkembangan intelektual dan afeksional anak usia sekolah ini.

Peran lingkungan keluarga bagi masa remaja dan adolesen, juga sangat penting dan relatif menentukan kepribadian dan kompetensi anak pada periode perkembangan berikutnya. Pada fase "building an identity" di masa remaja ini, "model-person" dari orang tua menjadi sebuah pilihan anakanaknya. Implikasinya, sikap orang tua terhadap remajanya diperlukan kehadirannya sebagai "model pilihan" anak. Kepribadian orang tua, termasuk idealisme, komitmen,

28 Dwi Nirmala, Pelaksanaan Pendidikan Karakter Pada Anak Usia Dini di Lembaga PAUD, Yayasan Taman Asuh Anak Terpadu Qurrota A'yun Malang (Skripsi, Universitas Muhammadiyah Malang, 2012). 
kompetensi, integritas, pola hidup, sentuhan rasa, dan lainnya merupakan sumber inspiratif bagi remajanya untuk mengonstruksi identitas yang dicarinya. Di sinilah, keluarga menjadi penentu atau pemengaruh dominan kepribadian dan identitas anak remajanya yang hendak melintasi fase dewasa. Komunikasi resiprokal yang intens dan demokratis diperlukan pada masa ini. Penelitian Offer, Ostrov, dan Howard (1982) menggarisbawahi bahwa "hubungan keluarga pada masa prapubertas memberi kesan dan pengalaman baik bagi masa remajanya. Kualitas komunikasi orangtua-anak merupakan kunci penentu remaja yang sehat. Semakin baik kualitas komunikasi orang tua - anak, semakin positif citra diri remajanya kelak" ${ }^{29}$ Dalam fase ini, orang tua sebagai bagian penting keluarga, diharapkan memiliki kesungguhan komitmen, konsep ideal untuk mengomunikasikan nilai-nilai, termasuk nilai toleransi dan keyakinan beragama, serta memberikan sentuhan rasa secara intensif dan terarah sebagai pijakan dan konsep diri untuk dirumuskan dan diidentifikasi anak remajanya agar kelak di masa "dewasa"nya bisa menjadi pribadi matang (fully functional person) menurut Carl Rogers.

Ketiga, peran keluarga selanjutnya pada remaja, yang berada pada fase pencarian otonomi, ${ }^{30}$ menjadi sangat penting

29 D., E. Ostrov Offer dan K.I. Howard, "Family Perceptions of Adolescent Self-Image", Journal of Youth and Adolescent 11 (4): 281-191.

30 Pada fase menjelang dewasa (anak muda), menurut Laurence Steinberg dan Susan Silverberg (1986), adolesen mencari atau berusaha memperoleh tiga bentuk : (a) otonomi emosional (emotional autonomy), dimana adolesen ingin melepas ketergantungannya pada orang tua, dan 
dalam penyediaan standar, kriteria, dan pandangan-pandangan positif bagi masa depannya. Di masa ini, keluarga diharapkan mampu melakukan filterisasi dari pengaruh negatif kehidupan saat ini. Melalui keluarga, dengan peneladanannya akan menjadi model perilaku yang akan diidentifikasi bahkan diimitasi oleh anak. Melalui keluarga pula nilai-nilai, kebiasaan hidup sehari-hari, terseleksi dan tertanamkan pada anak. Pendekatan keluarga yang menekankan pada pemfungsian maksimal anggota keluarga dan lingkungannya, diharapkan upaya sosialisasi, disseminasi, dan penanaman sikap atau nilai toleransi beragama, seperti sikap mengakui keberadaan dan menghormati ajaran agama yang berbeda, sikap saling menghargai antarpemeluk agama, tidak diskriminatif terhadap pemeluk agama yang berbeda, memberikan hak dan kebebasan kepada pemeluk agama yang berbeda untuk menjalankan ibadahnya, serta membangun solidaritas dan kebersamaan hidup keseharian tanpa membedakan latar perbedaan agama yang dipeluknya, dapat dibangun secara efektif.

\section{PENUTUP}

Persaudaraan dan persatuan antarumat beragama dalam masyarakat majemuk sebagai wujud dari sikap toleransi dan

memulai hindup mandiri; (b) resistensi dari teman sejawat, dimana ingin lepas dari tekanan teman sejawat, dan (c) otonomi terkait dengan kemandirian diri (self-relience), menyangkut keinginan merasakan kebebasan untuk mencari dan mengontrol kehidupan sendiri. Lihat Lois Hoffman et.al., Developmental Psychology Today (New York: MacGrawHill, Inc, 1988), 357. 
kerukunan hidup antarumat beragama hanya dapat diciptakan melalui niat yang tulus dan ikhlas serta kejujuran dari semua pihak, dilandasi oleh pemahaman dan pengamalan yang lengkap dan benar terhadap ajaran agama masing-masing serta menaati perundang-undangan yang berlaku. Di samping, sudah barang tentu, pelibatan aktif yang tulus (instrinsik) serta keteladanan para pemimpin bangsa (tokoh masyarakat, pemimpin agama, birokrat, dsb.). Untuk meningkatkan dan membina toleransi dan kerukunan antarumat, perlu ditanamkan melalui pendidikan sejak dini secara komprehensif.

Pengembangan pendidikan agama dalam sistem pendidikan nasional yang berwawasan multikultural di tengah masyarakat Indonesia yang majemuk sangat penting penting untuk menumbuhkan sikap toleran. Begitu juga penanaman toleransi beragama melalui pendidikan dalam keluarga yang terimplementasikan dalam kehidupan sehari-hari sangat penting dalam pendasaran sikap toleransi dalam kehidupan manusia. Selain itu, kegiatan bersama antarumat beragama untuk kehidupan masyarakat, serta dialog secara terusmenerus untuk memelihara kerukunan merupakan hal yang harus dilakukan. Ketiga hal tersebut tentu saja harus dilakukan secara sinergis dan terus-menerus. 